\title{
Complex demographic heterogeneity from anthropogenic impacts in a coastal marine predator
}

\author{
Daniel Oro, ${ }^{1,2,5}$ David Álvarez, ${ }^{3}$ and Alberto Velando ${ }^{4}$ \\ ${ }^{1}$ Population Ecology Group, IMEDEA (CSIC-UIB), Esporles, Spain \\ ${ }^{2}$ Theoretical Ecology Lab, CEAB (CSIC), Blanes, Spain \\ ${ }^{3}$ Rio San Pedro 7, Oviedo, Spain \\ ${ }^{4}$ Departamento de Ecología y Biología Animal, Universidad de Vigo, Vigo, Spain
}

\begin{abstract}
Environmental drivers, including anthropogenic impacts, affect vital rates of organisms. Nevertheless, the influence of these drivers may depend on the physical features of the habitat and how they affect life history strategies depending on individual covariates such as age and sex. Here, the long-term monitoring (1994-2014) of marked European Shags in eight colonies in two regions with different ecological features, such as foraging habitat, allowed us to test several biological hypotheses about how survival changes by age and sex in each region by means of multi-event capture-recapture modeling. Impacts included fishing practices and bycatch, invasive introduced carnivores and the severe Prestige oil spill. Adult survival was constant but, unexpectedly, it was different between sexes. This difference was opposite in each region. The impact of the oil spill on survival was important only for adults (especially for females) in one region and lasted a single year. Juvenile survival was time dependent but this variability was not synchronized between regions, suggesting a strong signal of regional environmental variability. Mortality due to bycatch was also different between sex, age and region. Interestingly the results showed that the size of the fishing fleet is not necessarily a good proxy for assessing the impact of bycatch mortality, which may be more dependent on the fishing grounds and the fishing gears employed in each season of the year. Anthropogenic impacts affected survival differently by age and sex, which was expected for a longlived organism with sexual size dimorphism. Strikingly, these differences varied depending on the region, indicating that habitat heterogeneity is demographically important to how environmental variability (including anthropogenic impacts) and resilience influence population dynamics.
\end{abstract}

Key words: anthropogenic impacts; habitat heterogeneity; life histories; long-lived species; resilience; survival.

\section{INTRODUCTION}

Anthropogenic impacts (e.g., the agents of global change) play a role in environmental variability that is both stochastic and deterministic. Thus, they may influence most ecological processes and patterns at the level of individuals, populations, communities and ecosystems. This influence depends on the magnitude and duration of the impact (pulse vs. press perturbations), the resilience capacity and the evolutionary life histories of the species affected. At a population level, age and sex are two features of individuals whose vital rates may also be differently affected by environmental variability with consequences for gene frequencies, life histories, and population regulation. It is well known that age plays an important role in life history strategies and the ways in which they have been shaped by evolution, especially in age-structured populations of long-lived organisms

Manuscript received 4 October 2017; revised 30 November 2017; accepted 8 December 2017. Corresponding Editor: Dianne Brunton.

${ }^{5}$ E-mail: d.oro@csic.es
(Stearns 1992). For these organisms, vital rates such as survival, recruitment, and fertility fluctuate with environmental variability and mostly covarying positively with age until senescence (Charlesworth 1980, Charlesworth and Patridge 1997). Furthermore, sexual differences in age-dependent demographic parameters are well documented in species with sex-specific mating patterns and parental roles (Clutton-Brock and Isvaran 2007, Bonduriansky et al. 2008). Sex-specific demography may also be expected in monogamous species because sexes commonly differ in life history and ecological traits (Pärn et al. 2009, Saino et al. 2017). In seabirds, for example, males and females often differ in their foraging strategies with potential consequences on sexual differences in how environmental variability influences vital rates such as survival (Weimerskirch et al. 2014, Lewis et al. 2015). Life history theory predicts that those differences in vital rates between sexes and age classes should be maintained under environmental variability. Empirical studies show that, for instance, younger individuals always have lower vital rates than older, experienced individuals, and the sex investing more in reproduction always has a lower survival (Lebreton 
et al. 1992, Loison et al. 1999). Nevertheless, some recent evidence indicates that environmental variability may alter the patterns of fixed variation of vital rates with age and sex (Steiner et al. 2010, Pardo et al. 2012, Oro et al. 2014).

Apart from age and sex, other factors that may alter how environmental variability affects vital rates, such as local habitat features, are rarely considered. These features may induce differential susceptibility to mortality, including that from human activities (e.g., oil spills [Álvarez and Pajuelo 2004], seabird bycatch [Gianuca et al. 2017]). This is likely because habitat affects niche segregation among age and sex classes (Cook et al. 2013, Thiebot et al. 2014, Genovart et al. 2017). Understanding how anthropogenic impacts affect the different individual features such as sex and age within and between populations is crucial to assessing how these perturbations influence the spatiotemporal dynamics of populations and their viability. This may be particularly important to reliably diagnose the different impacts of global change and the potential heterogeneity in resilience between populations, particularly for vulnerable species and communities (e.g., Oro et al. 2012).

Here, we test the interaction between foraging habitat and anthropogenic impacts on age- and sex-specific survival of a sexually size-dimorphic coastal seabird, the European Shag (Phalacrocorax aristotelis), hereafter "Shag." We take advantage of a long-term monitoring program of this species in two close Atlantic regions of the Iberian Peninsula, Western (W) Asturias (Cantabrian coast) and Rías Baixas (Galicia), with contrasting ecological features and anthropogenic impacts (see Fig. 1a,b). In these two regions, Shags have no competing species and are the only piscivorous pursuit-diving seabird. Shags also show marked habitat-dependent differences in foraging strategies (Watanuki et al. 2008): in W Asturias, Shags mainly use rocky shores, where typically they are solitary foragers and search for benthic fish, such as wrasses (family Labridae; Álvarez 1998, Moreno et al. 2011), moving along the bottom (Watanuki et al. 2008). In Rías Baixas, Shags frequently forage in groups to catch sandeels (family Ammodytidae, mainly Gymnammodytes semisquamatus) in shallow, sandy areas (Velando and Freire 1999, Velando and Munilla 2008; see Fig. 1c). We evaluated three anthropogenic impacts during the study period that likely affected age- and sex-dependent survival variability of Shags: (1) bycatch in fishing gears, (2) mortality due to the Prestige oil spill (see Fig. 1b), and (3) predation by an introduced invasive carnivore, the American mink (Neovison vison). The influence of environmental and anthropogenic factors on Shags are expected to depend on individual covariates such as age and sex due to, for example, differences in their foraging strategies (Daunt et al. 2007, Bogdanova et al. 2014, Lewis et al. 2015) and behavior (Nelson 2005).

\section{Biological hypotheses}

As for all long-lived organisms, we expect an increase in survival with age, due to the acquisition of experience
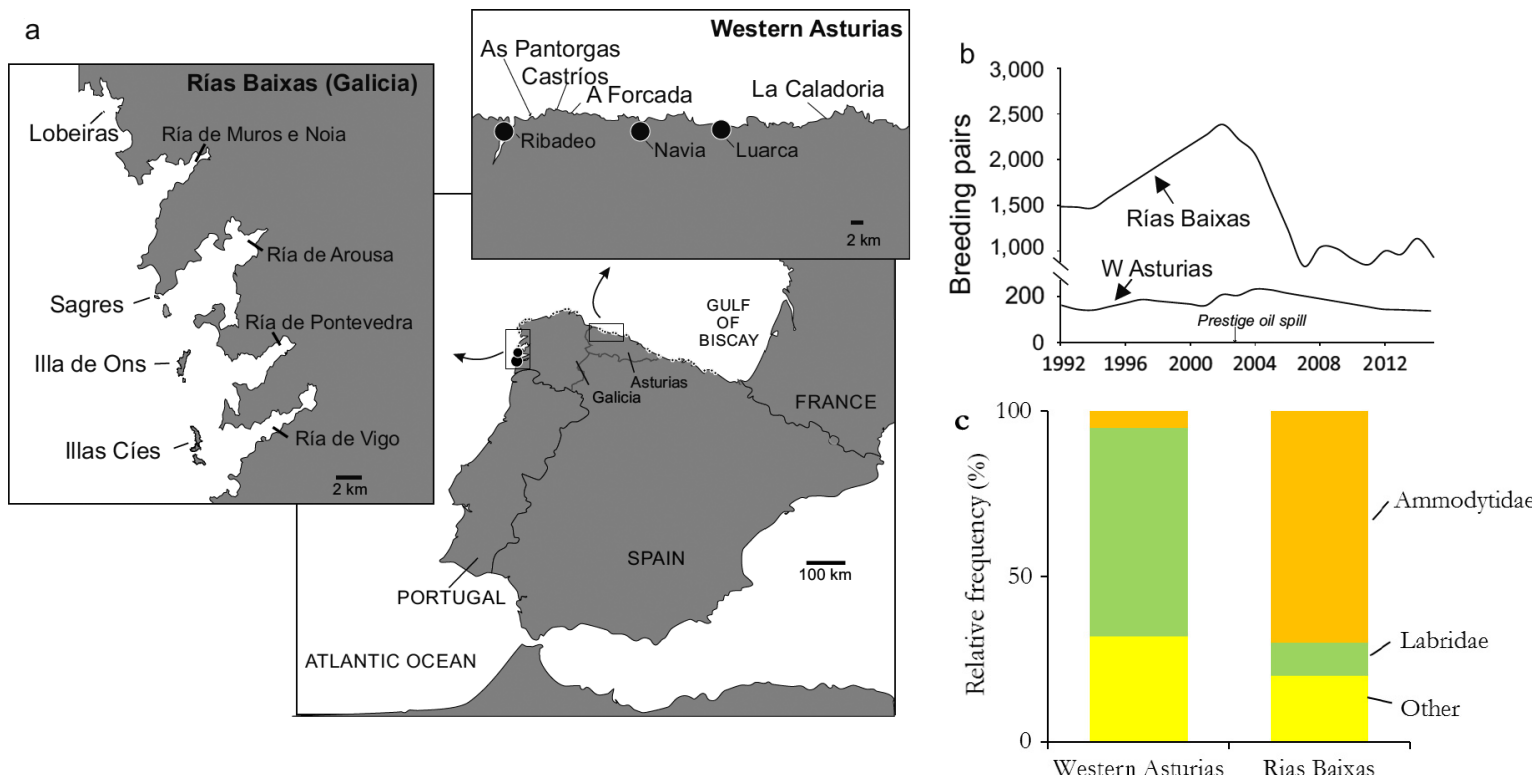

FIG. 1. Study area and Shag population. (a) Distribution of the main colonies (black dots) of the European shag on the Atlantic coast of Spain; the location of the study colonies in the two study regions are shown in the panels. (b) Estimated breeding population changes in these regions between 1992 and 2014 and occurrence of the Prestige oil spill. (c) Relative frequency (\%) of prey fishes during the breeding period in western Asturias (based on 1,446 prey from 114 fresh pellets collected in 1998 and 2004; Álvarez 1998, Moreno et al. 2011) and Rías Baixas (25,330 prey from 1,003 pellets collected from 1992 to 2007; Velando and Munilla 2008). 
and a selection filter acting mostly on juvenile individuals. Since environmental canalization should increase with age (Gaillard and Yoccoz 2003), we also expect that juvenile survival will vary over time, whereas adult survival will be constant, although extreme perturbations could also affect the latter (Frederiksen et al. 2008). Juveniles have poorer foraging skills compared to adults, and increase their foraging effort to compensate (Daunt et al. 2007). During the post-fledgling period, juveniles strongly compete and males are more aggressive than females (Velando 2000). In relation to sex, survival of adult males, likely with lower reproductive costs than females, should be higher (e.g., Tavecchia et al. 2001). In birds, reproductive costs, more than size dimorphism, have a strong impact on sex-specific adult mortality (Owens and Bennett 1994). Additionally, if sex-specific foraging costs are related to habitat characteristics, sex differences in mortality between regions may occur. Male and female seabirds also respond differently to environmental fluctuations (Barros et al. 2013b, Lewis et al. 2015) and they show different foraging strategies (e.g., Bogdanova et al. 2014). Male Shags are constrained by the defense of their breeding territory, even during the non-breeding season (Snow 1960), which may restrict their foraging area. Some preliminary evidence in the study area suggests that sex and age affect susceptibility to human-related mortality (Martinez-Abrain et al. 2006, Álvarez 2015).

In both study regions, Shags are incidentally caught by artisanal gillnet fisheries (Velando and Freire 2002, Álvarez 2015). The number of artisanal fishing vessels is higher in Rías Baixas than in W Asturias, so we expected a lower survival for all ages and sexes in the former region, although the different foraging strategies driven by habitat differences may affect bycatch susceptibility.

On 13 November 2002, the Prestige oil tanker released about 63,000 metric tons of heavy oil close to the Galician coast. This spill was the largest environmental perturbation recorded in the Iberian Peninsula. Shags were affected by the initial spillage (Velando et al. $2005 a, b)$ with a long-term decrease at the population level (Velando and Munilla 2008, Barros et al. 2014; see Fig. 1b). The pre-spill long-term monitoring in Rías Baixas (oiled) and W Asturias (unoiled) colonies allowed us to distinguish between the effects of the spillage event and natural temporal and spatial variability: we expected an especially high impact of the oil spill on juvenile survival in Rías Baixas, since most Shag casualties were juveniles (Velando et al. 2005b), whereas we expected a lack of impact in the distant W Asturias. Importantly, some evidence suggests that female mortality was higher in the aftermath of the oil spill, probably due to sexual segregation in foraging habitats (Martinez-Abrain et al. 2006). Last, some Rías Baixas colonies were affected by the presence of invasive American mink (Velando et al. 2017), with severe episodes of predation on adult Shags (Barros et al. 2016).
Methods

Study area and species

We studied Shag populations in two regions in the northwestern Iberian Peninsula (see Fig. 1) from 1994 to 2014. Shags are year-round local residents in the study area (Velando and Munilla 2008, Barros et al. 2013a), showing high natal and breeding fidelity, with most birds recruiting within $5 \mathrm{~km}$ of their natal site (Velando and Freire 2002, Barros et al. 2013b). Young birds visit the colonies in their first year of life and most birds recruit at age 3 with a few recruiting at age 2 (Velando 2001, Velando and Freire 2002, Velando and Munilla 2008, see also Frederiksen et al. 2008).

The two study regions have contrasting oceanographic and ecological features. In the Rías Baixas in southern Galicia, Shags breed on large islands surrounded by sandy shallow waters in the mouth of rías (i.e., drowned river valleys open to the sea; Fig. 1a). In contrast, Shag colonies in W Asturias are located on small islets and cliffs along the rocky shores of the mainland coast. River discharges and coastal upwellings (from March to October) strongly enhance marine productivity in the Rías Baixas coast, which is higher than in W Asturias, which is less influenced by upwelling dynamics (Bode et al. 2011). This likely explains the higher number of fishing vessels in Rías Baixas compared to Asturias (MAGRAMA 2012). In Rías Baixas, we monitored four breeding colonies (Cíes, Ons, Sagres, and Lobeiras; Fig 1a), where population density has fluctuated between $\sim 800$ and 2,400 estimated breeding pairs since 1992 (Fig. 1b). After the Prestige oil spill, the breeding population was about $70 \%$ lower than before the spill (Álvarez and Velando 2007, Velando et al. 2015; Fig. 1b). In W Asturias, fieldwork was conducted on four small islets (As Pantorgas, Castríos-Represas, A Forcada and La Caladoria; Fig. 1a), which have a relatively stable population of about 150-200 pairs, although a decline in the number of breeding pairs in recent years has been recorded (D. Álvarez, unpublished data; Fig. 1b).

The ringing program was carried out during 1994 2014. A total of 2,428 birds were marked, most of them as chicks (92\% from total) and the rest as adults, all in the nests during the breeding season (annual median, 98 birds; range, 11-454). Color-ringed Shags were easily detected and monitored at colonies as evidenced by previous studies (Velando 2000, Velando and Freire 2002, Noguera et al. 2012, Barros et al. 2013b). Only two age classes (juveniles and adults) were considered to avoid an over-parameterization of survival models. Animals were marked in different colonies (Fig. 1a). Because the colonies are larger in Rías Baixas, more birds were marked in this region ( $76 \%$ from total).

In the monitored areas, blood samples (about $0.5 \mathrm{~mL}$ ) or feathers were taken from some chicks (about $0.5 \mathrm{~mL}$ ) and sex was determined by molecular analysis or by means of a discriminant function in chicks older than 
25 d (Velando et al. 2002 correctly sexed over 97\% of the chicks; see details in Barros et al. 2013b). Adults were sexed based on vocalizations, size, and behavior; the same percentage of males and females were recorded using these criteria ( $24 \%$ of each sex, the rest remaining unsexed). From 1995 to 2014, we collected resighting data by intensive field monitoring of marked Shags in the study areas. Only resights performed during the breeding season were used in our analysis. The rest of the birds could not be sexed mostly due to cases in which ringed chicks were never resighted. To improve survival estimates and to estimate the sources of mortality, we used 118 recoveries from dead marked birds. The cause of death could be assigned in $48 \%$ of the cases. Most cases $(95 \%)$ corresponded to birds that died in fishing gear (vertical gill-nets; Álvarez 2015). The three cases of birds that died due to the oil spill were assigned to the unknown category because of a lack of power to obtain mortality estimates from this cause of death.

\section{Capture-recapture statistical modeling}

We applied a multi-event capture-recapture modeling to our data, which included a mixture of capture-resighting data and recoveries of dead animals. In this modeling approach, we relate the true states of the individuals to the observed events through a series of conditional probabilities (Pradel 2005). This modeling also allowed us to deal with the presence of transients (likely an age effect) and trap heterogeneity, with some birds being more accessible to resighting than others. In fact, a multi-state goodness-of-fit test (GOF) performed only on marked chicks showed that those two effects (transients and trap heterogeneity) were strong in the two regions and that the fit of the JMV model was very poor (see Table 1). Models were built using E-SURGE (Choquet et al. 2009) and

TABLE 1. Multi-state goodness-of-fit test (GOF) performed using U-Care (Choquet 2009) on birds marked as chicks only.

\begin{tabular}{lrrc}
\hline \hline GOF component and region & \multicolumn{1}{c}{$\chi^{2}$} & $\mathrm{df}$ & $P$ \\
\hline Test3G & & & \\
$\quad$ Western Asturias & 140.111 & 14 & $<0.0001$ \\
$\quad$ Rías Baixas & 30.997 & 15 & $<0.01$ \\
Test M & & & \\
$\quad$ Western Asturias & 73.152 & 19 & $<0.0001$ \\
$\quad$ Rías Baixas & 68.710 & 18 & $<0.0001$ \\
JMV model & & & \\
$\quad$ Western Asturias & 108.872 & 41 & $<0.0001$ \\
$\quad$ Rías Baixas & 265.264 & 50 & $<0.0001$ \\
\end{tabular}

Notes: The data set was a mixture or recaptures and recoveries. $\chi^{2}$, chi-square test value; $\mathrm{df}$, degrees of freedom. Test $3 \mathrm{G}$ examines the effect of the past capture history on the future of animals captured and released at the same time on the same site; Test $\mathrm{M}$ contrasts the animals not caught at a given occasion, yet known to be alive, to those caught at the same occasion; JMV model generalizes the Arnason-Schwarz model by allowing encounter probabilities to vary by site occupied at the previous occasion, so it test whether all animals present at any given time at the same site behave the same. identified three basic types of parameters: the initial state probabilities, the transition probabilities between states and the event probabilities. Model selection was based on QAIC, the Akaike Information Criterion corrected for overdispersion (Burnham and Anderson 2002).

We analysed all data available from 1994 to 2014 and, as previously, individuals were classified into two groups based on their age at first capture (juveniles and adults). Models included nine biological states: alive aware (AAM and AAF for males and females, respectively), alive unaware (AUM and AUF), individuals recently dead as bycatch (RFM and RFF), individuals recently dead due to unknown causes (RDM and RDF) and dead (D), with this last state being unobservable. Transitions between states were modeled in two steps: survival and probability of dying in bycatch events. On each capture-recapture occasion $(t$ ’'), we considered 10 possible events: individual not seen (noted 0 ), individual seen as male (noted 1), male found recently dead as bycatch (noted 2), male found recently dead due to unknown causes (noted 3), individual seen as female (noted 4), female found recently dead as bycatch (noted 5), female found recently dead due to unknown causes (noted 6), individual seen of unknown sex (noted 7), individual of unknown sex found recently dead as bycatch (noted 8) and individual of unknown sex found recently dead due to unknown causes (noted 9) (see details in Appendix S1). The events were used for modeling sex assignment (testing for differences in region and sex) and recovery probabilities (testing for differences in region and cause of mortality).

The setup of the event matrix was conservative, in the sense that recoveries of birds that died due to unknown reasons were not partially assigned to bycatch mortality (see Appendix S1). This was done even when birds assigned to unknown reasons were likely deceased due to bycatch (birds with hidden hooks or drowned in vertical nets and stranded in beaches). Nevertheless, the small number of recoveries precluded the estimation of a probability that birds dead due to unknown causes had died due to fisheries. Thus, our estimation of fishery bycatch must be considered as a minimum probability of mortality from this anthropogenic impact; we also increased the reliability of our estimates of bycatch mortality.

Age, sex, and region were the covariates tested in our models for all parameters. Survival and recaptures were allowed to vary with time, whereas probabilities of dying as bycatch and unknown causes were set as constant over the years because of the low number of recoveries (i.e., lack of power). Two other anthropogenic impacts were also tested in our models: the Prestige oil spill, occurring in southern Galicia in the winter of 2002 (with a before-after-control-impact (BACI) design), and the arrival of invasive American mink to the Cíes archipelago in 2009. Since Shags ringed at Cíes largely contributed to the pool of ringed birds in Rías Baixas, the severe episodes of predation may have produced a signature on demographic parameters in this area. 


\section{Results}

Most marked birds (82\%) were never resighted, likely because many fledglings died during their first months of life before recruiting. In fact, from the 118 recoveries, $75 \%$ corresponded to birds in their first year of life. A total of 981 resights were made at the colonies. In general, there was considerable uncertainty around the estimates, likely caused by the relatively small sample sizes and the low resighting probabilities for some sexage-location classes. For instance, and due to logistic (e.g., long-lasting harsh sea conditions that precluded the access to the colonies, lack of funding) and biological constraints (e.g., total breeding failure), some cohorts of chicks could not be ringed.

Since GOF tests were statistically significant, we included age and trap-awareness in our models and then corrected for the remaining overdispersion with a $\hat{c}=2.087$. We started modeling with a more general model (see Appendix S2: Table S1) in which both survival and recapture varied with time, age, sex, and region; mortalities in fisheries varied with age, sex, and region; sex assignment varied with region and sex; and finally, recoveries varied with region and cause of death. We first modeled sex assignment and recoveries starting by simplifying the more general model, in which survival of all ages, sexes and regions were set as constant. The best model (model 2, Appendix S2: Table S1) showed that sex assignment depended on the region (but not on sex) and recovery rates depended on region and cause of death. Starting from model 2, we then modeled the minimum probabilities of dying in fisheries (Appendix S2: Table S2). Region in particular, but also sex and age, were important covariates for these probabilities (models 9, 10, and 11, respectively, Appendix S2: Table S2). We then tried to assess whether region influenced ages or sexes differently: after testing for different combinations of region, age, and sex, the selected model showed that age played an important role only in Rías Baixas, but sex was important in the two regions for the minimum probabilities of dying in fisheries (model 13, Appendix S2: Table S2). Starting from model 13, we modeled recapture probabilities. None of the models tested improved the fit of this model; thus region, age and time were important, whereas sex did not influence these probabilities (model 22, see Appendix S2: Table S3). Finally, we modeled survival probabilities taking account of sex, region, age, and time, and the potential effects of the Prestige oil spill and the arrival of invasive minks (Appendix S2: Table S4).

Adult survival was constant and different between regions and sexes (models 29 and 35, Appendix S2: Table S4). The potential impact of the Prestige oil spill on survival was important only for adults from Rías Baixas and only the year after the spill (model 46, Appendix S2: Table S4). A well ranked model suggested that mortality due to the Prestige oil spill mostly affected female birds from Rías Baixas (model 47, Appendix S2: Table S4). We did not detect a statistically significant effect of American mink on survival for birds breeding in Rías Baixas. All three of the best models (models 35, 46, and 47) showed that sex was not important for juvenile survival in either region, but that survival for this age class varied with time and differently for each region (thus, there was no additive effect of region, see Fig. 2a). In the two regions, juvenile survival varied greatly over time ranging from low $(0.17,95 \%$ CI $0.08-0.30$ and 0.15 , 95\% CI 0.04-0.44 for W Asturias and Rías Baixas, respectively) to high values for first-year survival $(0.64$, 95\% CI $0.42-0.81$ and $0.66,95 \%$ CI $0.43-0.83$ for W Asturias and Rías Baixas, respectively, see Fig. 2a). Despite showing different fluctuations over time in each region, juvenile survival was on average similar in the two regions. Adult survival was much higher than the mean juvenile survival and remained constant, although it varied with sex differently in the two regions. In W Asturias, males survived more than females, and the contrary was true for Rías Baixas (see Fig. 2b). The difference was due to the low adult survival for males in Rías Baixas, since survival for adult females was similar in the two regions (Fig. 2b). Adult survival in Rías Baixas greatly decreased the year after the Prestige oil spill: from $0.72(95 \%$ CI $0.68-0.76)$ to $0.67(0.63-0.70)$ for males and from $0.80(0.75-0.84)$ to $0.62(95 \%$ CI 0.59-0.64) for females, which was the most affected of the two sexes. The best models all showed that a minimum mortality due to bycatch was also different between sex, age, and region: in W Asturias, both juvenile and adult females were more impacted than males, whereas in Rías Baixas, adults and juveniles of each sex were similarly affected (Fig. 2c). Recapture probabilities varied with years, age, region and sex (only for adults); recaptures were, in general, higher for adult males than for adult females and higher in Rías Baixas than in Asturias, whereas for juveniles they were higher in Asturias than in Rías Baixas (see Appendix S3).

\section{Discussion}

Our study shows that anthropogenic impacts may differently affect survival of a coastal marine predator depending not only on age and sex but also on habitat features. The consequences of these impacts on survival and the resulting heterogeneity is probably the result of the complex interaction of life history strategies (e.g., breeding investment by each sex, high population elasticity for adult survival) with proximal factors, such as the characteristics of foraging habitat and resilience mechanisms to buffer against each of the impacts. This plasticity is crucial to understand the responses of organisms to environmental variability for the theory of life history strategies (Caswell 1983). Even within seabird communities, responses to a common environment can be very different depending on life history strategies, the patterns of competition, stochasticity (both environmental and demographic), and the strength of density-dependence (Jenouvrier et al. 2005, Rolland et al. 2010, Almaraz and Oro 2011). 

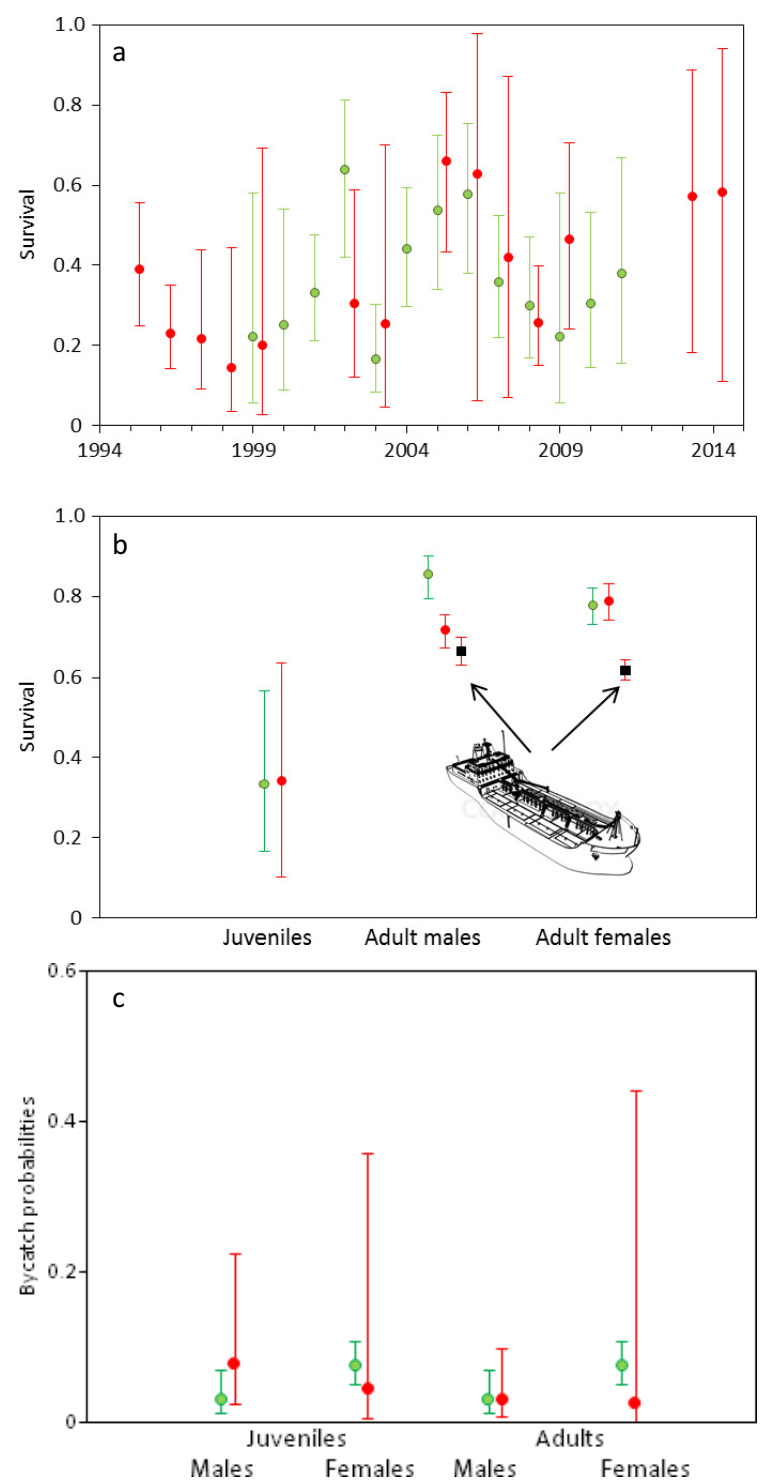

FIG. 2. (a) Annual variation of juvenile survival of European shags in western Asturias and Rías Baixas (solid and open dots, respectively, in all panels) during 1994-2014. For those years when no fledglings were marked, first-year survival could not be estimated and these values are missing. (b) Survival for adult males and females for each region; open squares show the single annual survival value after the Prestige oil spill for birds breeding at Rias Baixas. For juvenile survival, a mean value from a constant model is shown. (c) The minimum probability of dying as fisheries bycatch for each region, age, and sex; note that for Asturias, only sex played an important role and bycatch mortality for juveniles and adults were the same. Mean and $95 \% \mathrm{CI}$ are shown in all panels.

\section{Anthropogenic impacts on survival}

Our study indicates that bycatch has a non-negligible impact on Shag demography in both regions, and that it was the most severe and long-lasting of the impacts recorded here. The bycatch incidence was similar in the two regions even though the difference in the size of the fishing fleets $(\sim 4,500$ and 250 boats in Rías Baixas and Asturias, respectively; see INDUROT 2010, Ouréns et al. 2010). This suggests that fishing fleet size is not necessarily a good proxy to assess bycatch impact on top marine predators, especially for artisanal coastal boats, which have a high spatiotemporal variability in fishing gears, fishing operations, targeted species, and location of fishing grounds (Laneri et al. 2010, Lewison et al. 2014). On the contrary, mortality from bycatch on age and sex classes did show regional differences: in $\mathrm{W}$ Asturias, but not in Rías Baixas, female Shags (both juvenile and adults) are more likely to be caught in fishing nets than males. A recent study by De Rijcke (2015) shows that Shag males dive deeper and have higher postdiving intervals than females when foraging in kelpforested benthic areas. Sexual segregation in foraging niches and its effect on sex-specific bycatch may be more relevant in deep habitats, where Shags capture benthic prey, than in shallow waters where Shags forage on pelagic prey. Sex differences in seabird bycatch have been found in several fisheries (reviewed in Gianuca et al. 2017), but their demographic signature has rarely been explored, probably due to the difficulties in obtaining and integrating recoveries into complex capture-recapture models (e.g., Genovart et al. 2017).

Seabirds are one of the most affected organisms in large oil spills, but their demographic effects are difficult to understand without long-term monitoring of marked individuals (Wiens 2007, Votier et al. 2008). In our study, the temporal comparison (BACI design) between oiled (Rías Baixas) and unoiled colonies (W Asturias) confirms that adult survival was severely affected by the impact of the Prestige oil spill. Although most Shags retrieved during the spillage were juveniles (Velando et al. 2005b), we could not detect any oil spill effect on juvenile survival. Two non-exclusive hypotheses can explain this mismatch: first, the age structure of the population may be formed by a large proportion of juveniles, and thus, stranded birds were found according to their frequency in the population. Second, juvenile mortality from the oil spill was probably masked by environmental variability strongly affecting over-winter mortality (e.g., occurrence of storms, low food availability; Harris and Wanless 1996, Votier et al. 2008, Oro et al. 2010). On the contrary, despite the fact that few adults were found stranded, we found that adult survival was reduced by $\sim 15 \%$ the year after the Prestige oil spill. In this oil spill, only a small fraction of the dead birds were retrieved (Munilla et al. 2011), but adult survival impairment may also be explained by the sublethal effects of oil exposure or reduced food availability after the oil spill (Velando et al. $2005 b$, 2010). A reduction in breeder survival likely explains the overall population decline in the breeding season following the Prestige disaster (Velando et al. 2005a). This is in agreement with the fact that in longlived organisms such as Shags, population dynamics have a high elasticity to variations of adult survival (Martínez- 
Abraín et al. 2001, Doherty et al. 2004). Juvenile survival varied differently over time in each region suggesting than local oceanographic conditions and temporal variability in anthropogenic impacts were more important drivers than those occurring at a macro-scale, driven by large climatic indexes such as NAO (Oro 2014). However, the mean value of juvenile survival over time was similar in the two regions.

Finally, invasive carnivores such as feral cats and mustelids, are known to cause severe damage to seabird colonies worldwide (Towns et al. 2011). In our study, an effect of American mink on survival for birds breeding in Rías Baixas (if any) was not detected, perhaps because the impact was present only on the Cíes archipelago and the colonies that remained undisturbed diluted that mortality. In Cíes, severe predation on adult Shags was recorded in the year when mink arrived in the breeding colonies, but subsequently Shags moved to safe nest sites inaccessible to terrestrial carnivores, which probably minimized predator impact (Barros et al. 2016). This behavioural buffering against the arrival of terrestrial predators is partly explained by adaptive plasticity to varying environments, which is especially high for some seabirds such as terns and gulls (Martínez-Abraín et al. 2003, Payo-Payo et al. 2017), whereas other species, particularly Procellariforms, have evolved in very stable environments and lack adaptive responses to this type of perturbation (Igual et al. 2007).

\section{Demographic consequences of survival heterogeneity between ages, sexes and habitats}

As expected for a long-lived organism (Stearns 1992), adult survival was higher than that of juveniles, and the former was more stable over time, except when a severe impact occurred (i.e., the Prestige oil spill). Adult survival was different between regions, and this likely influenced local population dynamics (e.g., Fernández-Chacón et al. 2013). This was particularly evident after the occurrence of an extreme event (the oil spill, see Fig. 1b) (see also Frederiksen et al. 2008). Sex has also been highlighted as an important individual feature affecting seabird survival, especially for dimorphic species (Promislow et al. 1992, Oro et al. 2010). The sex-skewed mortality from the oil spill in Galicia towards adult females was likely an additive factor for the population decline due to an altered population sex ratio (see also Mills and Ryan 2005, Martinez-Abrain et al. 2006, Veran and Beissinger 2009). Importantly, the recorded time series from Rías Baixas (Fig. 1b) shows that the oil spill likely caused a regime shift and that population still remains at a much lower density after 15 years, even though adult survival recovered its normal values after the event (see also Harris and Wanless 1996, Lewison et al. 2012). It may be that there has been a lack of rescue immigration from source populations (Sanz-Aguilar et al. 2016), that a regime shift for the whole coastal ecosystem around the affected colonies occurred, lowering the carrying capacity and preventing a hysteresis loop after cessation of the impact by demographic buffering (e.g., increased recruitment and fertility, decreased emigration; e.g., Oro et al. 2012), and/or the negative effect of other persisting impacts, mainly bycatch, may be at play. Mortality from bycatch was also different between sexes, but again only in one region. This difference between regions was due to differences in the features of fishing fleets and foraging habitat, and the foraging behavior in each region (see also Weimerskirch et al. 1997, Rolland et al. 2010, Bugoni et al. 2011). Furthermore, varying oceanographic conditions at a small spatial scale can drive differential seabird population dynamics (Anderson 1989).

In summary, demographic parameters of seabird populations may vary with environmental variability in a complex way, involving individual (e.g., age, sex, social rank, breeding status) and population (e.g., densitydependence, stable age distribution) features. Even closely situated populations sharing the same environment can show different demographic responses and vital rates, because intrinsic population features such as age structure or density-dependence may alter that relationship (Tavecchia et al. 2008, Sanz-Aguilar et al. 2009). Furthermore, anthropogenic impacts are not only part of environmental variability, but they also introduce more complexity to the responses of organisms at ecological and evolutionary levels (Lewison et al. 2012, Oro et al. 2013). Some of these impacts are deterministic (e.g., habitat loss, anthropogenic perturbation events), some generate different patterns of mortality (e.g., additive, compensatory), and some may affect different components of the ecosystems altering the relationships between organisms (e.g., predator-prey, interference competition within communities). In addition, demographic responses may vary depending on population resistance and resilience, which depend on the duration of the impact, the life history of the species, habitat heterogeneity and availability, population size (e.g., Allee effects) and others (Jiguet et al. 2007). Our study illustrates how major anthropogenic impacts for seabirds, namely oil spills, fishery bycatch and introduced carnivores, can have very different demographic consequences depending on individual responses to the perturbations and habitat features.

\section{ACKNOWLEDGMENTS}

Meritxell Genovart helped with statistical analysis and Simone Tenan gently offered logistic support at MUSE. We are grateful to the staff at the Parque Nacional Illas Atlánticas de Galicia for logistic support all over the study period. We are especially grateful to Manuel Fernández Pajuelo, Alvaro Barros, Cristóbal Pérez, Ignacio Munilla, and Francisco Docampo for their assistance in fieldwork. A reviewer provided helpful comments to improving the draft.

\section{Literature Cited}

Almaraz, P., and D. Oro. 2011. Size-mediated non-trophic interactions and stochastic predation drive assembly and dynamics in a seabird community. Ecology 92:1948-1958. 
Álvarez, D. 1998. The diet of shags Phalacrocorax aristotelis in the Cantabrian Sea, northern Spain, during the breeding season. Seabird 20:22-30.

Álvarez, D. 2015. Análisis de la mortalidad de las poblaciones de cormorán moñudo (Phalacrocorax aristotelis) en artes de pesca en la Demarcación Marina Noratlántica. Technical Report. Ministerio de Agricultura, Alimentación y Medio Ambiente, Madrid, Spain.

Álvarez, D., and M. A. F. Pajuelo. 2004. Differential migration in a wintering population of common guillemots Uria aalge affected by the Prestige oil spill. Ardeola 51:451-454.

Álvarez, D., and A. Velando. 2007. El Cormorán moñudo en España y Gibraltar. Población en 2006-2007 y método de censo. SEO/Birdlife, Madrid, Spain.

Anderson, D. J. 1989. Differential responses of boobies and other seabirds in the Galapagos to the 1986-87 El NinoSouthern Oscillation event. Marin Ecology Progress Series 52:209-216.

Barros, A., D. Álvarez, and A. Velando. 2013a. Cormorán moñudo - Phalacrocorax aristotelis. In A. Salvador and M. B. Morales, editors. Enciclopedia Virtual de los Vertebrados Españoles. Museo Nacional de Ciencias Naturales, Madrid, Spain. http://www.vertebradosibericos.org/aves/phaari.html

Barros, A., D. Álvarez, and A. Velando. 2013b. Climate influences fledgling sex ratio and sex-specific dispersal in a seabird. PLoS ONE 8:e71358.

Barros, Á., D. Álvarez, and A. Velando. 2014. Long-term reproductive impairment in a seabird after the Prestige oil spill. Biology Letters 10:20131041.

Barros, Á., R. Romero, I. Munilla, C. Pérez, and A. Velando. 2016. Behavioural plasticity in nest-site selection of a colonial seabird in response to an invasive carnivore. Biological Invasions 18:3149-3161.

Bode, A., R. Anadón, X. A. G. Morán, E. Nogueira, E. Teira, and M. Varela. 2011. Decadal variability in chlorophyll and primary production off NW Spain. Climate Research 48: 293-305.

Bogdanova, M. I., S. Wanless, M. P. Harris, J. Lindström, A. Butler, M. A. Newell, K. Sato, Y. Watanuki, M. Parsons, and F. Daunt. 2014. Among-year and within-population variation in foraging distribution of European shags Phalacrocorax aristotelis over two decades: Implications for marine spatial planning. Biological Conservation 170:292-299.

Bonduriansky, R., A. Maklakov, F. Zajitschek, and R. Brooks. 2008. Sexual selection, sexual conflict and the evolution of ageing and life span. Functional Ecology 22:443-453.

Bugoni, L., K. Griffiths, and R. W. Furness. 2011. Sex-biased incidental mortality of albatrosses and petrels in longline fisheries: differential distributions at sea or differential access to baits mediated by sexual size dimorphism? Journal of Ornithology 152:261-268.

Burnham, K. P., and D. R. Anderson. 2002. Model selection and multimodel inference: A practical information-theoretic approach. Springer Science \& Business Media, New York, NY.

Caswell, H. 1983. Phenotypic plasticity in life-history traits: demographic effects and evolutionary consequences. Integrative and Comparative Biology 23:35-46.

Charlesworth, B. 1980. Evolution in age-structured populations. Cambridge University Press, Cambridge, UK.

Charlesworth, B., and L. Patridge. 1997. Levelling of the grim reaper. Current Biology 7:R440-R442.

Choquet, R., L. Rouan, and R. Pradel. 2009. Program E-surge: a software application for fitting multievent models. Pages 845-865 in D. L. Thomson, E. G. Cooch and M. J. Conroy, editors. Modeling demographic processes in marked populations. Springer US, New York, NY.
Clutton-Brock, T. H., and K. Isvaran. 2007. Sex differences in ageing in natural populations of vertebrates. Proceedings of the Royal Society B 274:3097-3104.

Cook, T. R., A. Lescroël, Y. Cherel, A. Kato, and C.-A. Bost. 2013. Can foraging ecology drive the evolution of body size in a diving endotherm? PLoS ONE 8:e56297.

Daunt, F., V. Afanasyev, A. Adam, J. P. Croxall, and S. Wanless. 2007. From cradle to early grave: juvenile mortality in European shags Phalacrocorax aristotelis results from inadequate development of foraging proficiency. Biology Letters 3:371374.

De Rijcke, S. 2015. Foraging behaviour of the European shag during early chick-rearing period; do they follow the marginal value theorem? Thesis. Norwegian University of Science and Technology, Trondheim, Norway.

Doherty Jr, P. F., E. A. Schreiber, J. D. Nichols, J. E. Hines, W. A. Link, G. A. Schenk, and R. W. Schreiber. 2004. Testing life history predictions in a long-lived seabird: a population matrix approach with improved parameter estimation. Oikos 105:606-618.

Fernández-Chacón, A., M. Genovart, R. Pradel, G. Tavecchia, A. Bertolero, J. Piccardo, M. G. Forero, I. Afán, J. Muntaner, and D. Oro. 2013. When to stay, when to disperse and where to go: survival and dispersal patterns in a spatially structured seabird population. Ecography 36:1117-1126.

Frederiksen, M., F. Daunt, M. P. Harris, and S. Wanless. 2008. The demographic impact of extreme events: stochastic weather drives survival and population dynamics in a longlived seabird. Journal of Animal Ecology 77:1020-1029.

Gaillard, J.-M., and N. G. Yoccoz. 2003. Temporal variation in survival of mammals: a case of environmental canalization? Ecology 84:3294-3306.

Genovart, M., D. F. Doak, J.-M. Igual, S. Sponza, J. Kralj, and D. Oro. 2017. Varying demographic impacts of different fisheries on three Mediterranean seabird species. Global Change Biology 23:3012-3029.

Gianuca, D., R. A. Phillips, S. Townley, and S. C. Votier. 2017. Global patterns of sex- and age-specific variation in seabird bycatch. Biological Conservation 205:60-76.

Harris, M. P., and S. Wanless. 1996. Differential responses of Guillemot Uria aalge and Shag Phalacrocorax aristotelis to a late winter wreck. Bird Study 43:220-230.

Igual, J. M., M. G. Forero, T. Gomez, and D. Oro. 2007. Can an introduced predator trigger an evolutionary trap in a colonial seabird? Biological Conservation 137:189-196.

INDUROT. 2010. Análisis y caracterización socioeconómica de la flota pesquera artesanal asturiana. Principado de Asturias, Oviedo, Spain.

Jenouvrier, S., C. Barbraud, and H. Weimerskirch. 2005. Longterm contrasted responses to climate of two Antarctic seabird species. Ecology 86:2889-2903.

Jiguet, F., A.-S. Gadot, R. Julliard, S. E. Newson, and D. Couvet. 2007. Climate envelope, life history traits and the resilience of birds facing global change. Global Change Biology 13:1672-1684.

Laneri, K., M. Louzao, A. Martínez-Abraín, J. M. Arcos, E. J. Belda, J. Guallart, A. Snchez, M. Gimnez, R. Maestre, and D. Oro. 2010. Trawling regime influences longline seabird bycatch in the Mediterranean: new insights from a small-scale fishery. Marine Ecology Progress Series 420:241-252.

Lebreton, J.-D., K. P. Burnham, J. Clobert, and D. R. Anderson. 1992. Modeling survival and testing biological hypothesis using marked animals: a unified approach with case studies. Ecological Monographs 62:67-118.

Lewis, S., R. A. Phillips, S. J. Burthe, S. Wanless, and F. Daunt. 2015. Contrasting responses of male and female foraging 
effort to year-round wind conditions. Journal of Animal Ecology 84:1490-1496.

Lewison, R., et al. 2012. Research priorities for seabirds: improving conservation and management in the 21 st century. Endangered Species Research 17:93-121.

Lewison, R. L., et al. 2014. Global patterns of marine mammal, seabird, and sea turtle bycatch reveal taxa-specific and cumulative megafauna hotspots. Proceedings of the National Academy of Sciences USA 111:5271-5276.

Loison, A., M. Festa-Bianchet, J.-M. Gaillard, J. T. Jorgenson, and J.-M. Jullien. 1999. Age-specific survival in five populations of ungulates: evidence of senescence. Ecology 80:2539-2554.

MAGRAMA. 2012. Estrategia marina de la demarcación marina noratlántica. Ministerio de Agricultura, Alimentación y Medio Ambiente, Madrid, Spain.

Martinez-Abrain, A., A. Velando, D. Oro, M. Genovart, C. Gerique, M. A. Bartolom, E. Villuendas, and B. Sarzo. 2006. Sex-specific mortality of European shags after the Prestige oil spill: demographic implications for the recovery of colonies. Marine Ecology Progress Series 318:271-276.

Martínez-Abraín, A., D. Oro, and J. Jiménez. 2001. The dynamics of a colonization event in the European shag: the roles of immigration and demographic stochasticity. Waterbirds 24: 97-102.

Martínez-Abraín, A., D. Oro, M. G. Forero, and D. Conesa. 2003. Modeling temporal and spatial colony-site dynamics in a long-lived seabird. Population Ecology 45:133-139.

Mills, M. S. L., and P. G. Ryan. 2005. Modelling impacts of long-line fishing: what are the effects of pair-bond disruption and sex-biased mortality on albatross fecundity? Animal Conservation 8:359-367.

Moreno, R., L. Jover, A. Velando, I. Munilla, and C. Sanpera. 2011. Influence of trophic ecology and spatial variation on the isotopic fingerprints of seabirds. Marine Ecology Progress Series 442:229-239.

Munilla, I., J. M. Arcos, D. Oro, D. Álvarez, P. M. Leyenda, and A. Velando. 2011. Mass mortality of seabirds in the aftermath of the Prestige oil spill. Ecosphere 2:1-14.

Nelson, B. 2005. Pelicans, cormorants and their relatives: Pelecanidae, Sulidae, Phalacrocoracidae, Anhingidae, Fregatidae, Phaethontidae. Oxford University Press, Oxford, UK.

Noguera, J. C., S.-Y. Kim, and A. Velando. 2012. Pre-fledgling oxidative damage predicts recruitment in a long-lived bird. Biology Letters 8:61-63.

Oro, D. 2014. Seabirds and climate: knowledge, pitfalls, and opportunities. Frontiers in Ecology and Evolution 2:79.

Oro, D., R. Torres, C. Rodriguez, and H. Drummond. 2010. Climatic influence on demographic parameters of a tropical seabird varies with age and sex. Ecology 91:1205-1214.

Oro, D., J. Jiménez, and A. Curcó. 2012. Some clouds have a silver lining: paradoxes of anthropogenic perturbations from study cases on long-lived social birds. PLoS ONE 7:e42753.

Oro, D., M. Genovart, G. Tavecchia, M. S. Fowler, and A. Martínez-Abraín. 2013. Ecological and evolutionary implications of food subsidies from humans. Ecology Letters 16:1501-1514.

Oro, D., N. Hernández, L. Jover, and M. Genovart. 2014. From recruitment to senescence: food shapes the age-dependent pattern of breeding performance in a long-lived bird. Ecology 95:446-457.

Ouréns, R., G. Cambié, S. Carabel, and J. Freire. 2010. Gestión pesquera, sostenibilidad y conservación de la biodiversidad en el archipiélago de las Islas Cíes, en el Parque Nacional de las Islas Atlánticas de Galicia. Universidade da Coruña \& Ministerio de Medio Ambiente, Medio Rural y Marino, A Coruña, Spain.
Owens, I. P. F., and P. M. Bennett. 1994. Mortality costs of parental care and sexual dimorphism in birds. Proceedings of the Royal Society B 257:1-8.

Pardo, D., C. Barbraud, M. Authier, and H. Weimerskirch. 2012. Evidence for an age-dependent influence of environmental variations on a long-lived seabird's life-history traits. Ecology 94:208-220.

Pärn, H., H. Jensen, T. H. Ringsby, and B.-E. Sæther. 2009. Sex-specific fitness correlates of dispersal in a house sparrow metapopulation. Journal of Animal Ecology 78:1216-1225.

Payo-Payo, A., M. Genovart, A. Sanz-Aguilar, J. Greño, M. García-Tarason, A. Bertolero, J. Piccardo, and D. Oro. 2017. Colonisation in social species: the importance of breeding experience for dispersal in overcoming information barriers. Scientific Reports 7:42866 in press.

Pradel, R. 2005. Multievent: an extension of multistate capture-recapture models to uncertain states. Biometrics 61: 442-447.

Promislow, D. E. L., R. Montgomerie, and T. E. Martin. 1992. Mortality costs of sexual dimorphism in birds. Proceedings of the Royal Society B 250:143-150.

Rolland, V., H. Weimerskirch, and C. Barbraud. 2010. Relative influence of fisheries and climate on the demography of four albatross species. Global Change Biology 16:1910-1922.

Saino, N., R. Ambrosini, M. Caprioli, A. Romano, M. Romano, D. Rubolini, C. Scandolara, and F. Liechti. 2017. Sex-dependent carry-over effects on timing of reproduction and fecundity of a migratory bird. Journal of Animal Ecology 86:239-249.

Sanz-Aguilar, A., B. Massa, F. Lo Valvo, D. Oro, E. Minguez, and G. Tavecchia. 2009. Contrasting age-specific recruitment and survival at different spatial scales: a case study with the European storm petrel. Ecography 32:637-646.

Sanz-Aguilar, A., J. M. Igual, G. Tavecchia, M. Genovart, and D. Oro. 2016. When immigration mask threats: The rescue effect of a Scopoli's shearwater colony in the Western Mediterranean as a case study. Biological Conservation 198:33-36.

Snow, B. 1960. The breeding biology of the shag Phalacrocorax aristotelis on the island of Lundy, Bristol Channel. Ibis 102:554-575.

Stearns, S. C. 1992. The evolution of life histories. Oxford University Press, New York, New York, USA.

Steiner, U. K., S. Tuljapurkar, and S. H. Orzack. 2010. Dynamic heterogeneity and life history variability in the kittiwake. Journal of Animal Ecology 79:436-444.

Tavecchia, G., R. Pradel, V. Boy, A. R. Johnson, and F. Cézilly. 2001. Sex- and age-related variation in survival and cost of first reproduction in greater flamingos. Ecology 82:165-174.

Tavecchia, G., E. Minguez, A. De LeÇün, M. Louzao, and D. Oro. 2008. Living close, doing differently: Small-scale asynchrony in demography of two species of seabirds. Ecology 89:77-85.

Thiebot, J.-B., Y. Cherel, M. Acqueberge, A. Prudor, P. N. Trathan, and C.-A. Bost. 2014. Adjustment of pre-moult foraging strategies in Macaroni Penguins Eudyptes chrysolophus according to locality, sex and breeding status. Ibis 156 : 511-522.

Towns, D., G. Byrd, H. Jones, M. Rauzon, J. Russell, and C. Wilcox. 2011. Impacts of introduced predators on seabirds. Pages 56-90 in C. P. H. Mulder, W. B. Anderson, D. R. Towns, and P. J. Bellingham, editors. Seabird islands: ecology, invasion, and restoration. Oxford University Press, New York, New York, USA.

Velando, A. 2000. The importance of hatching date for dominance in young shags. Animal Behaviour 60:181-185.

Velando, A. 2001. Postfledging crèche behavior in the European shag. Journal of Ethology 19:121-127. 
Velando, A., and J. Freire. 1999. Intercolony and seasonal differences in the breeding diet of European shags on the Galician coast (NW Spain). Marine Ecology Progress Series 188:225-236.

Velando, A., and J. Freire. 2002. Population modelling of European shags (Phalacrocorax aristotelis) at their southern limit: conservation implications. Biological Conservation 107: 59-69.

Velando, A., and I. Munilla. 2008. Plan de Conservación del Cormorán Moñudo en el Parque Nacional de las Islas Atlánticas. Universidade de Vigo, Vigo, Spain.

Velando, A., J. Graves, and J. E. Ortega-Ruano. 2002. Sex ratio in relation to timing of breeding, and laying sequence in a dimorphic seabird. Ibis 144:9-16.

Velando, A., D. Álvarez, J. Mouriño, F. Arcos, and A. Barros. 2005a. Population trends and reproductive success of European Shag following the Prestige oil spill in the Iberian Peninsula. Journal of Ornithology 146:116-120.

Velando, A., I. Munilla, and P. M. Leyenda. 2005b. Short-term indirect effects of the 'Prestige' oil spill on European shags: changes in availability of prey. Marine Ecology Progress Series 302:263-274.

Velando, A., I. Munilla, M. López-Alonso, J. Freire, and C. Pérez. 2010. EROD activity and stable isotopes in seabirds to disentangle marine food web contamination after the Prestige oil spill. Environmental Pollution 158:1275-1280.

Velando, A., Á. Barros, and P. Moran. 2015. Heterozygosityfitness correlations in a declining seabird population. Molecular Ecology 24:1007-1018.
Velando, A., P. Morán, R. Romero, J. Fernández, and V. Piorno. 2017. Invasion and eradication of the American mink in the Atlantic Islands National Park (NW Spain): a retrospective analysis. Biological Invasions 19:1227-1241.

Veran, S., and S. R. Beissinger. 2009. Demographic origins of skewed operational and adult sex ratios: perturbation analyses of two-sex models. Ecology Letters 12:129-143.

Votier, S. C., T. R. Birkhead, D. Oro, M. Trinder, M. J. Grantham, J. A. Clark, R. H. McCleery, and B. J. Hatchwell. 2008. Recruitment and survival of immature seabirds in relation to oil spills and climate variability. Journal of Animal Ecology 77:974-983.

Watanuki, Y., F. H. J. Daunt, A. Takahashi, M. A. Newell, S. Wanless, K. Sato, and N. Miyazaki. 2008. Microhabitat use and prey capture of a bottom-feeding top predator, the European Shag, shown by camera loggers. Marine Ecology Progress Series 356:283-293.

Weimerskirch, H., N. Brothers, and P. Jouventin. 1997. Population dynamics of wandering albatross Diomedea exulans and Amsterdam albatross D. amsterdamensis in the Indian Ocean and their relationships with long-line fisheries: conservation implications. Biological Conservation 79:257-270.

Weimerskirch, H., Y. Cherel, K. Delord, A. Jaeger, S. C. Patrick, and L. Riotte-Lambert. 2014. Lifetime foraging patterns of the wandering albatross: Life on the move!. Journal of Experimental Marine Biology and Ecology 450:68-78.

Wiens, J. A. 2007. Applying ecological risk assessment to environmental accidents: harlequin ducks and the Exxon Valdez oil spill. BioScience 57:769-777.

\section{SUPPORTING INFORMATION}

Additional supporting information may be found online at: http://onlinelibrary.wiley.com/doi/10.1002/eap.1679/full

Data Availability

Data available from the Spanish Research Council CSIC: https://doi.org/10.20350/digitalcsic/8523 